\title{
Влияние эффекта Пельтье на границе ВCM- Si(Mn), содержащей пористость, на процесс инжекции носителей заряда
}

\author{
В.В. Клечковская ${ }^{1)}$, А.С. Орехов ${ }^{1)}$, Т.С. Камилов ${ }^{2)}$, А.С. Рысбаев ${ }^{2)}$,К.К. Курбаналиев ${ }^{2)}$ \\ ${ }^{1}$ Институт кристаллографии им. А.В. Шубникова ФНИЦ «Кристаллография и фотоника» РАН, \\ 119333, Москва, Ленинский просп., 59, Россия \\ ${ }^{2}$ Ташкентский государственный технический университет, 100095, Ташкент, ул. Университетская \\ 2, Узбекистан \\ тел:+7 (499) 135-3500, эл. почта: klechvv@ns.crys.ras.ru
}

DOI 10.34077/RCSP2019-144

Исследование электрических и фотоэлектрических свойств кремния, легированного марганцем $(\mathrm{Si}<\mathrm{Mn}>)$, проводилось в течение длительного времени [1]. В дальнейшем изучались физикохимические процессы, происходящие в приповерхностном слое и в объемной части кремния при диффузионном легировании марганцем из паровой фазы. Было показано, что при диффузии $\mathrm{Mn}$ в $\mathrm{Si}$ на поверхности кремния происходит образование высшего силицида марганца (BCM) $\mathrm{Mn}_{4} \mathrm{SI}_{7}$.

Исследуемые диоды $\mathrm{Mn}_{4} \mathrm{Si}_{7}-\mathrm{Si}<\mathrm{Mn}>-\mathrm{Mn}_{4} \mathrm{Si}_{7}$ и $\mathrm{Mn}_{4} \mathrm{SI}_{7}-\mathrm{Si}<\mathrm{Mn}>-\mathrm{M}$ изготавливали с помощью диффузионного легирования кремния марки КДБ-10 марганцем. Параметры исследуемой гетероструктуры при $\mathrm{T}=300 \mathrm{~K}$ : слой $\mathrm{BCM}\left(\mathrm{Mn}_{4} \mathrm{Si}_{7}\right)$ имеет толщину $7-10$ мкм, проводимость $\sigma \approx 20$ $(\mathrm{OM} \cdot \mathrm{cm})^{-1}, \quad p$-типа с концентрацией носителей $\sim 10^{19}-10^{20} \mathrm{~cm}^{-3}$; база структуры $\mathrm{Si}<\mathrm{Mn}>$ проводимостью $i$-типа с концентрацией носителей $10^{11}-10^{12} \mathrm{~cm}^{-3}$; площадь токовых контактов ВСМ и $\mathrm{M}-2 \cdot 10^{-2} \mathrm{~cm}^{-2}$ : длина базовых областей - от 0,3 до $1 \mathrm{~cm}$. Контакт (M) создавался путем нанесения сплавов $\mathrm{NiGa}$ или $\mathrm{AlGa}$. Электрические и фотоэлектрические характеристики структур снимались непосредственно в жидком азоте, а также в специальном криостате. В качестве источника света использовался арсенид галлиевый светодиод, интенсивность излучения которого регулировалась заданием прямого тока диода. Переходная область структуры и ее элементный состав на границе раздела $\mathrm{BCM}-\mathrm{Si}<\mathrm{Mn}>$ исследовалась методами электронной дифракции и электронной микроскопии. При измерении Фото-ВАХ установлено, что при значениях фототока $I_{\phi} 4 \cdot 10^{-4} \mathrm{~A}$ происходило пузырьковое кипение жидкого азота, а при токах свыше $I_{\phi} \geq 10^{-3}$ A происходило пленочное кипение на приграничной области контакта, т.е. на границе раздела $\mathrm{Mn}_{4} \mathrm{Si}_{7}$ и $\mathrm{Si}<\mathrm{Mn}>$. Методом фокусированного ионного пучка галлия $\mathrm{Ga}^{+}$был приготовлен поперечный срез пленки ВСМ на подложке кремния. Методом сканирующей электронной микроскопии выявлено наличие пористого слоя вдоль границы раздела $\mathrm{Mn}_{4} \mathrm{Si}_{7}$ и $\mathrm{Si}<\mathrm{Mn}>$. Расстояние между порами в среднем составляло t 1-1,5 мкм. Установлено, что контакты $\mathrm{Si}-\mathrm{Mn}_{4} \mathrm{SI}_{7}$ имеют не сплошной характер, «стягивание» линий тока к контактным точкам может приводить к появлению в подобной области повышенного сопротивления и, соответственно, локального выделения высокой электрической мощности и нагрев Пельтье. На основе исследований гетероструктур при низких температурах установлено, что освещение собственным светом при фототоке $I_{p h} \geq 1 \mathrm{ma}$, и нагрев вследствие эффекта Пельтье, приводят к существенному перегреву границы раздела, обусловленному фототермоэлектрическим эффектом. Фототермоэлектрический эффект на границе раздела $\mathrm{Mn}_{4} \mathrm{Si}_{7} \mathrm{c}$ $\mathrm{Si}<\mathrm{Mn}>$ (нагрев Пельтье) и поры на границе раздела силицида с кремнием приводят к разделению фотогенерированных носителей заряда (электронов и дырок), вследствие чего на порядки усиливается фоточувствительность гетероструктур.

\section{Лuтература}

[1] Т.С.Камилов, В.В.Клечковская и др. Электрические и фототермоэлектричекие свойства гетерофазных структур на основе кремния и силицидов марганца. - Ташкент.: MERIYUS , 2014. 180 стр. 